\title{
Retrospective study of the occurrence of Cyclospora cayetanensis at Clinical Hospital of the University of São Paulo Medical School, SP
}

\author{
Estudo retrospectivo da ocorrência de Cyclospora cayetanensis \\ no Hospital das Clínicas da Faculdade de Medicina \\ da Universidade de São Paulo, SP
}

\author{
Elenice Messias do Nascimento Gonçalves ${ }^{1}$, Iaiko Horroiva Uemura ${ }^{1}$, Vera Lúcia Pagliusi \\ Castilho $^{1}$ and Carlos Eduardo Pereira Corbett ${ }^{2}$
}

\begin{abstract}
Cyclospora cayetanensis causes watery diarrhea in tropical countries, among travelers and after ingestion of contaminated water and food. Very little is known about its epidemiology, pathogenic aspects and reservoirs. In Brazil, its prevalence is unknown and to date there have been reports of three outbreaks. We report here a retrospective study of 5,015 stool samples from 4,869 patients attended at Clinical Hospital of the University of São Paulo Medical School, SP, Brazil between April 1996 and January 2002, with 14 cases of Cyclospora cayetanensis being detected there was a prevalence of $0.3 \%$. Of the 14 infected patients, the mean age was 38 years and $71.4 \%$ were female. Ten patients presented symptoms; six presented levels of immunological markers and five patients were immunodeficient.
\end{abstract}

Key-words: Cyclospora cayetanensis. Prevalence. Cyclosporiasis. Parasitology. Pathology. Brazil.

\section{RESUMO}

Cyclospora cayetanensis causa diarréia líquida em países tropicais, viajantes e após ingestão de água e alimentos contaminados. Muito pouco é conhecido sobre sua epidemiologia, aspectos patogênicos e reservatórios. № Brasil, sua prevalência é desconhecida com relato de três surtos. Nós relatamos um estudo retrospectivo de 5.015 amostras fecais provenientes de 4.869 pacientes atendidos no Hospital das Clínicas da Faculdade de Medicina da Universidade de São Paulo, SP, Brasil entre abril de 1996 e janeiro de 2002 com detecção de 14 casos de ciclosporíase e prevalência de 0,3\%. Deste total 71,4\% eram do sexo feminino com idade média de 38 anos. Dez apresentaram sintomatologia, seis tinham níveis de marcadores imunológicos e cinco imunodeficiência.

Palavras-chaves: Cyclospora cayetanensis. Prevalência. Ciclosporíase. Parasitologia. Patologia. Brasil.

Cyclospora cayetanensis is an emerging and opportunistic coccidium, first described as a causal agent of human infection in 19794; it was included in the Cyclospora genus in $1993^{20}$ with referenced species in $1994^{19}$. To date, 17 species of Cyclospora have been identified through the use of molecular methods, although humans are the only host of Cyclospora cayetanensis and no animal model has been identified ${ }^{27}$. The exact means of transmission are still unknown; but it is probably by fecal-oral route, through the ingestion of sporulated oocysts, which are resistant to routine water treatment and pesticide use, since contaminated water and food account for the outbreaks ${ }^{17222329}$. It has, however, been detected in sputum, suggesting oocyst ingestion by aerosol ${ }^{8}$. The infection is characterized by watery diarrhea, weight loss, abdominal distension, flatulence, nausea, fatigue and low-grade fever. These symptoms can disappear in a few weeks or persist for months, or even be absent ${ }^{27}{ }^{29}$. The diagnostic routine of Cyclospora cayetanensis is based on the observation of non-sporulated oocysts measuring from 8 to

1. Central Laboratory Division. Clinical Hospital. University of São Paulo Medical School, São Paulo, SP. 2. Laboratory of Medical Investigation in Infectious Disease Pathology. University of São Paulo Medical School, São Paulo, SP.

Supported by DLC - HCFMUSP, LIM 03, LIM 50 \& CNPq.

Address to: Dr. Carlos Eduardo Pereira Corbett. Deptº de Patologia/FM/USP. Av. Dr. Arnaldo 455/1ํandar, sala 1215, 01246-903 São Paulo, SP, Brasil.

Telefax: 5511 3081-7799

e-mail: ccorbett@usp.br

Recebido para publicação em 4/2/2004

Aceito em 8/5/2005 
$10 \mu \mathrm{m}$ in stool smears stained by Kinyoun's modified method, also used for the detection of other coccidian parasites. It is necessary to measure these oocysts through a micrometer, since Cyclospora cayetanensis 0ocysts can be easily seen in phase contrast and fluorescence microscopes 121920 29. Oocyst sporulation in $2.5 \%$ potassium dichromate can also be used ${ }^{29}$. Cyclosporiasis has been reported in many countries, butitseems to be more common in tropical and subtropical regions ${ }^{2728}$. Its prevalence in Brazil is still unknown, with a case reported in Rio de Janeiro (RJ) ${ }^{24}$, a case in Brasilia (DF) ${ }^{3}, 10$ cases in the State of Goiás (GO) $)^{1314}, 3$ cases in Juiz de Fora (MG) ${ }^{6}$ and a case in São Paulo (SP) ${ }^{10}$. Three outbreaks have been registered: two in General Salgado (SP), one in November 2000 and another in January 2001, and the third in Antonina (PR), in November $2001^{112527}$. The objective was to perform a retrospective study of 5,015 stool samples, collected from 4,869 patients attended at Clinical Hospital of the University of São Paulo Medical School (HC-FMUSP) between April 1996 and January 2002, with 14 detected cases of Cyclospora cayetanensis.

\section{MATERIAL AND METHODS}

Clinical Hospital of the University of São Paulo Medical School (HCFMUSP), located in São Paulo, Brazil. This is a highly specialized public hospital, associated to the University of Sao Paulo with 3,271 beds and 9,888 employees and attends patients referred from the Public Health System and a small number of private patients as well as those with healthcare insurance. The Parasitology Service of the Division of the Central Laboratory of HC-FMUSP performs a monthly average of 10,000 parasitologic tests.

A retrospective study of 5,015 stool samples derived from 4,869 patients was conducted. The samples were sent to our Service for Cyclospora cayetanensis investigation, from April 1996 to January 2002. All samples were submitted to standard concentration methods: Hoffman, Pons and Janer, Faustand cols and modified Rugai method; they were stained with an iodine solution for the diagnosis of helminthes and protozoa (PPF). For the identification of Cyclospora cayetanensis, the Kinyoun's modified method ${ }^{12}$ was used in all samples, followed by oocyst sporulation in $2.5 \%$ potassium dichromate, whenever samples were positive. All oocysts were measured through an ocular micrometer. Samples were considered positive for Cyclospora cayetanensis when they presented spherical structures that stained in different shades of red, or colorless, with size varying from 8-10 $\mu \mathrm{m}$.

Statistical analysis. For the positive results, data such as age, sex, symptoms, diseases and immunological markers were collected from the hospital records using MS Office Excel version 2000. In order to characterize positive samples for Cyclospora cayetanensis, we present the relative and absolute frequencies of each qualitative variable. Regarding the quantitative variables, means and medians were used to summarize the data and standard errors, standard deviations, and minimum and maximum values were used to indicate data variability. To determine risk factors for Cyclospora cayetanensis, we compared the positive patients with 60 randomly selected patients, from the general population, with no infection. For the qualitative variables such as sex, diarrhea, disease and symptoms, we compared the frequency distribution between the positive and negative groups through Pearson's Chi-square test ${ }^{31}$. Fisher's exact test was used in situations where the expected values were lower than 5 . For $p$ values lower than 0.05 , we considered the association among the variables to be statistically significant. To compare the groups regarding the quantitative variables such as age, CD3, CD4, CD8 and CD4/CD8 ratio, we applied Student's t-test $^{31}$, in order to compare the means of the independent populations. For $p$ values lower than 0.05 , we considered that the two groups are different regarding patients' age.

\section{RESULTS}

Spherical organisms with a mean diameter of $9 \mu$ m, showing an internal granular structure and great acid-alcohol resistant staining variability were identified in 14 stool samples, diagnosed as Cyclospora cayetanensis ( Figure 1) and listed as follows:

1. MKG, 23-year-old single male, born and residing in São Paulo, artisan. He denied using tobacco, alcohol and illicit drugs. Patient was HIV-positive, homosexual, in a stable relationship. He lived with his parents. He came to the hospital complaining of persistent diarrhea for the previous 4 months, with 3 to 4 bowel movements a day. The patient had lost $17 \mathrm{~kg}$ in 5 months. In April 1996, his CD4 count was 104 T-cells/ $\mu \mathrm{l}$ and his stool sample was submitted to concentration and staining methods, which resulted positive for Cyclospora cayetanensis.

2. ASM, 42-year-old married female, residing in São Paulo and an employee at the Division of Nutrition and Dietetics of HC-FMUSP, during a routine parasitologic test in July 1997 she presented a diagnosis for the presence of Cyclospora cayetanensis in her stool sample. She had no symptoms or associated diseases.

3. RCS, 38-year-old single male, residing in São Paulo, homosexual. He was attended at the Extended Care Center for the HIV/AIDS patient, with AIDS symptoms and diarrhea, in September 1997. His stool sample was submitted to

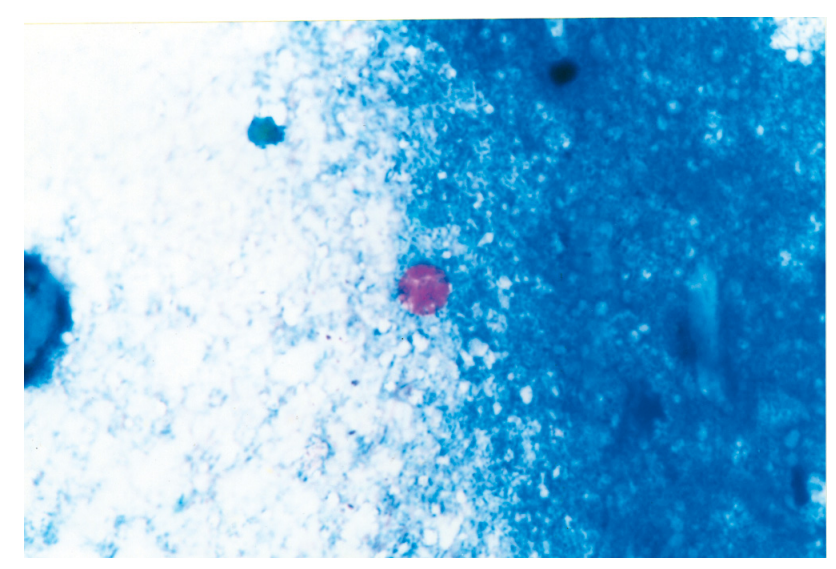

Figure 1 - Cyclospora cayetanensis, diameter of $9 \mu \mathrm{m}$, Kinyoun's modified method (1,000X magnification). 
concentration and staining methods, and was positive for Cyclospora cayetanensis; his CD4 T cell count was 162/ $\mu$ l.

4. LCS, 47-year-old widower, born in the State of Bahia and residing in São Paulo, with AIDS; she was attended at the Extended Care Center for the HIV/AIDS patient. In July 1999, she presented anorexia, loss of $20 \mathrm{~kg}$ of body weight in a 3month period, fever accompanied by productive cough with yellowish sputum, bloody-mucous diarrhea for a period of one year, with an average of ten bowel movements a day and swallowing difficulty. Her skin was dry and pale. CD4 T-cell count was 84 cells/ $\mu$ l; her stool sample was submitted to concentration and staining methods, and was positive for Entamoeba coli, Entamoeba histolytica/dispar, Schistosoma mansoni and Cyclospora cayetanensis.

5. IFNS, 50-year-old single male, homosexual, born in Rio de Janeiro, has been residing in São Paulo for 22 years. The patient was a smoker, but denied using illicit drugs. Patient had AIDS and came to the hospital for management of the disease, presenting good general health status and no gastrointestinal alterations. His CD4 T cell count was 126 cells/ $\mu \mathrm{l}$, and his stool sample was submitted to concentration and staining methods, and was positive for Cyclospora cayetanensis.

6. MSS, 57-year-old married female, born and residing in São Paulo. She denied using tobacco, alcohol or illicit drugs. In August 1999 she came to the hospital ER complaining of headache, nausea, and vomiting. She reported a loss of $2 \mathrm{~kg}$ in a 3-week period and bloody diarrhea for 20 days. Her CD4 T cell count was 73 cells/ $\mu$, and her stool sample test was positive for Cyclospora cayetanensis.

7. TAS, 24-year-old, single female, born in the State of Bahia and residing in São Paulo for 3 months. She reported sinusitis, bronchiectasia and hypogammaglobulinemia since childhood. She presented chronic diarrhea, with an average of 3 bowel movements a day. She came to the hospital for a clinical investigation at the Immunology Service. In September 2000, her CD4 T cell count was 295 cells/ $\mu$ l and her stool sample tested positive for Cyclospora cayetanensis.

8. LFC, 53-year-old married female, residing in Goiânia, State of Goiás. She underwent a laboratory investigation as a probable bone marrow donor in October 2000, with no diseases or symptoms. Laboratory tests were positive for hepatitis $\mathrm{C}$ and the parasitologic analysis of the stool revealed the presence of Cyclospora cayetanensis. She did not return to the Service.

9. ET, 40-year-old female, born and residing in General Salgado, São Paulo. She presented persistent diarrhea, with an average of 10 bowel movements a day. Her stool sample was submitted to laboratory investigation for the presence of probable etiologic agent, which was the cause of the diarrhea that affected inhabitants of that town in November 2000. The parasitologic analysis performed through concentration and staining methods was positive for Cyclospora cayetanensis.

10. OM, 30-year-old male, born and residing in General Salgado, SP. He presented persistent diarrhea, with an average of 10 bowel movements a day. His stool sample was submitted to laboratory investigation for the presence of probable etiologic agent, which was the cause of the diarrhea that affected inhabitants of that town in November 2000. The parasitologic analysis through concentration and staining methods was positive for Cyclospora cayetanensis.

11. MJCL, 40-year-old, married female, born and residing in São Paulo. The patient had hepatitis $\mathrm{C}$ and schizophrenia, with no gastrointestinal symptoms. She came to the hospital for routine management, and presented good general health status in January 2001. The parasitologic analysis was positive for Cyclospora cayetanensis.

12. ESS, 19-year-old, single female, born and residing in São Paulo. The patient had had Hodgkin's disease for 7 years. She denied tobacco, alcohol and illicit drug use. In February 2001, she came to hospital ER with fever, vomiting and diarrhea for a period of 3 days, with an average of 5 bowel movements a day. The stool sample analysis was positive for Cyclospora cayetanensis.

13. SGV, 20-year-old, single female, born and residing in São Paulo. She denied tobacco, alcohol and illicit drug use. The patient had sickle-cell anemia. In May 2001 she came to the hospital for a clinical investigation at the Hematology Service, presenting nausea, vomiting, abdominal pain and sporadic diarrhea. The parasitologic analysis through concentration and staining methods was positive for Cyclospora cayetanensis.

14. MJA, 53-year-old, married female, born and residing in São Paulo. In May 2001 she came to the hospital and was attended at the Gastroenterology Service of HCFMUSP, for a clinical investigation of chronic constipation. The stool sample analysis was positive for Blastocystis hominis and Cyclospora cayetanensis. She did not return to the Service.

Statistical analysis. The occurrence in this population was $0.3 \%$ (14/4869). Of the 14 infected patients, ten ( $71.4 \%)$ were females and $4(28.6 \%)$ were males. Age varied from 19 to 57 years with a mean age of 38 years. Ten $(71.4 \%)$ patients presented symptoms, with diarrhea being the most frequent (90\%) followed by vomiting ( $40 \%$, weightloss (30\%), nausea $(20 \%)$, fever $(10 \%)$, abdominal pain $(10 \%)$ and headache (10\%). Six (42.9\%) patients did not present established diseases and 5 (35.7\%) presented immunodeficiency, with 4 of these having AIDS and one hypogammaglobulinemia. Regarding the levels of immunological markers, only six patients presented these registers, as shown in Table 1.

When an inferential analysis was performed in order to determine the risk factors for Cyclospora cayetanensis, using

Table 1 - Descriptive statistics of levels of immunological markers.

\begin{tabular}{lccrrrrr}
\hline $\begin{array}{l}\text { Immunological } \\
\text { Marker }\end{array}$ & $\mathrm{n}^{\mathbf{0}}$ & Mean & Median & $\begin{array}{c}\text { Standard } \\
\text { Error }\end{array}$ & $\begin{array}{r}\text { Standard } \\
\text { Deviation }\end{array}$ & Minimum & Maximum \\
\hline CD3 & 6 & 872.3 & 932 & 208.58 & 510.91 & 304 & 1516 \\
CD4 & 6 & 140.7 & 115 & 33.48 & 82 & 73 & 295 \\
CD8 & 6 & 670.5 & 643 & 196.56 & 481.47 & 190 & 1268 \\
CD4/CD8 & 6 & 0.347 & 0.225 & 0.1342 & 0.3286 & 0.11 & 0.96 \\
\hline
\end{tabular}


the control group $(N=60)$ and the positive group $(N=14)$, we did not observe any statistically significant association between the presence of different symptoms $(p>0.05)$, diarrhea $(p>0.05)$, AIDS $(p>0.05)$, and the association of other parasites ( $p>0.05$ ) (Tables 2, 3, 4 and 5).

Table 2 - Results of the association regarding presence of symptoms.

\begin{tabular}{lrrrrr}
\hline & & \multicolumn{3}{c}{ Kinyoun } & \\
\cline { 3 - 4 } & & & negative & positive & Total \\
\hline Presence of symptom & no & $\mathrm{n}$ & 22 & 4 & 26 \\
& & $\%$ & 36.7 & 28.6 & 35.1 \\
& yes & $\mathrm{n}$ & 38 & 10 & 48 \\
& & $\%$ & 63.3 & 71.4 & 64.9 \\
\hline Total & $\mathrm{n}$ & 60 & 14 & 74 \\
& $\%$ & 100.0 & 100.0 & 100.0 \\
\hline
\end{tabular}

$\mathrm{p}$ value $=0.758$ (Fisher's exact test)

Table 3 - Results of the association regarding the presence of diarrhea.

\begin{tabular}{lrrrrr}
\hline & & \multicolumn{3}{c}{ Kinyoun } & \\
\cline { 3 - 5 } & & & negative & positive & Total \\
\hline Diarrhea & no & $\mathrm{n}$ & 30 & 5 & 35 \\
& & $\%$ & 50.0 & 35.7 & 47.3 \\
& yes & $\mathrm{n}$ & 30 & 9 & 39 \\
& & $\%$ & 50.0 & 64.3 & 52.7 \\
\hline Total & $\mathrm{n}$ & 60 & 14 & 74 \\
& & $\%$ & 100.0 & 100.0 & 100.0 \\
\hline
\end{tabular}

$\mathrm{p}$ value $=0.335$ (Chi-square test)

Table 4 - Results of the association regarding AIDS.

\begin{tabular}{lrrrrr}
\hline & & & \multicolumn{2}{c}{ Kinyoun } & \\
\cline { 3 - 5 } & & & negative & positive & Total \\
\hline AIDS & no & $\mathrm{n}$ & 33 & 10 & 43 \\
& & $\%$ & 55.0 & 71.4 & 58.1 \\
& yes & $\mathrm{n}$ & 27 & 4 & 31 \\
& & $\%$ & 45.0 & 28.6 & 41.9 \\
\hline Total & $\mathrm{n}$ & 60 & 14 & 74 \\
& & $\%$ & 100.0 & 100.0 & 100.0 \\
\hline
\end{tabular}

$\mathrm{p}$ value $=0.262$ (Chi-square test)

Table 5 - Results of the association regarding PPE.

\begin{tabular}{lrrrrr}
\hline & & & \multicolumn{2}{c}{ Kinyoun } & \\
\cline { 3 - 5 } & & & negative & positive & Total \\
\hline PFP & no & $\mathrm{n}$ & 45 & 12 & 57 \\
& & $\%$ & 75.0 & 85.7 & 77.0 \\
& yes & $\mathrm{n}$ & 15 & 2 & 17 \\
& & $\%$ & 25.0 & 14.3 & 23.0 \\
\hline Total & $\mathrm{n}$ & 60 & 14 & 74 \\
& & $\%$ & 100.0 & 100.0 & 100.0 \\
\hline
\end{tabular}

$\mathrm{p}$ value $=0.499$ (Fisher's exact test)

Regarding sex, Chi-square test results did not present statistically significant values at the usual level of $5 \%(p=0.058)$ but this test showed a slight concentration of females (71\%) in the infected group in comparison to $43.3 \%$ in the healthy group, as shown in Table 6 and Figure 2.

In relation to the quantitative variables: age, CD3, CD4, CD8 and CD4/CD8 ratio, we applied Students T-testand observed a statistically significant difference regarding CD4 only ( $p<0.001)$, with a mean of 141 cells/ $\mu \mathrm{l}$, as depicted in the Table 7 and Figure 3.
Table 6 - Results of the association regarding sex.

\begin{tabular}{lcrrrr}
\hline & & \multicolumn{3}{c}{ Cyclospora cayetanensis } \\
\cline { 3 - 5 } & & & negative & positive & Total \\
\hline Sex & female & $\mathrm{n}$ & 26 & 10 & 36 \\
& & $\%$ & 43.3 & 71.4 & 48.6 \\
& male & $\mathrm{n}$ & 34 & 4 & 38 \\
& $\%$ & 56.7 & 28.6 & 51.4 \\
\hline Total & $\mathrm{n}$ & 60 & 14 & 74 \\
& & $\%$ & 100.0 & 100.0 & 100.0
\end{tabular}

$\mathrm{p}$ value $=0.058$ (Chi-square test)

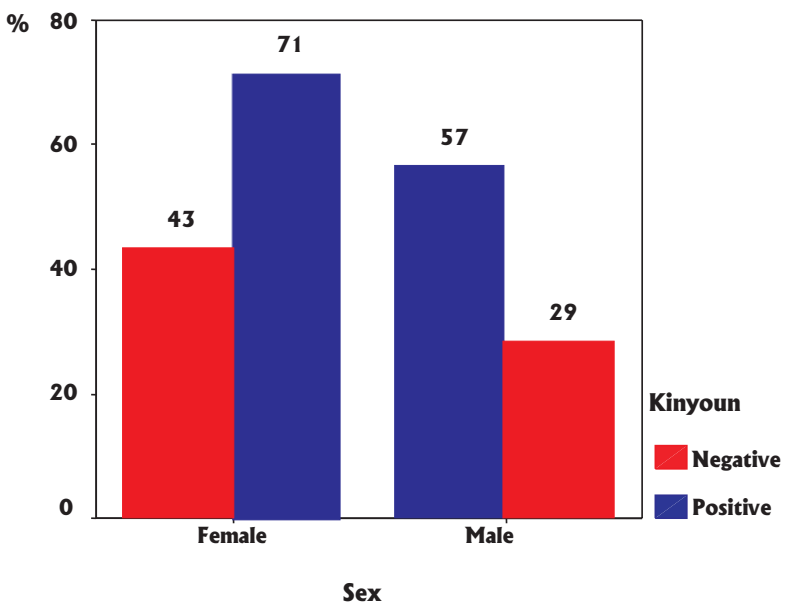

Figure 2 - Concentrations of positive and negative results for Cyclospora cayetanensis, according to sex.

Table 7 - Results of the comparison of means for the quantitative variables.

\begin{tabular}{llrrrc}
\hline & Knyoun & $\mathrm{N}$ & Mean & $\mathrm{SD}$ & $\mathrm{p}$-value (T-test) \\
\hline Age & negativo & 60 & 30.63 & 15.27 & 0.088 \\
& positive & 14 & 38.29 & 13.09 & \\
CD3 & negative & 27 & 1607.9 & 989.90 & 0.089 \\
& positive & 6 & 872.33 & 510.91 & \\
CD4 & negative & 27 & 442.93 & 364.44 & $<0.001 *$ \\
& positive & 6 & 140.67 & 82.00 & \\
CD8 & negative & 27 & 1051.4 & 790.19 & 0.151 \\
& positive & 6 & 670.50 & 481.47 & \\
CD4/CD8 & negative & 27 & 0.604 & 0.630 & 0.175 \\
& positive & 6 & 0.346 & 0.328 & \\
\hline
\end{tabular}

*statistically significant

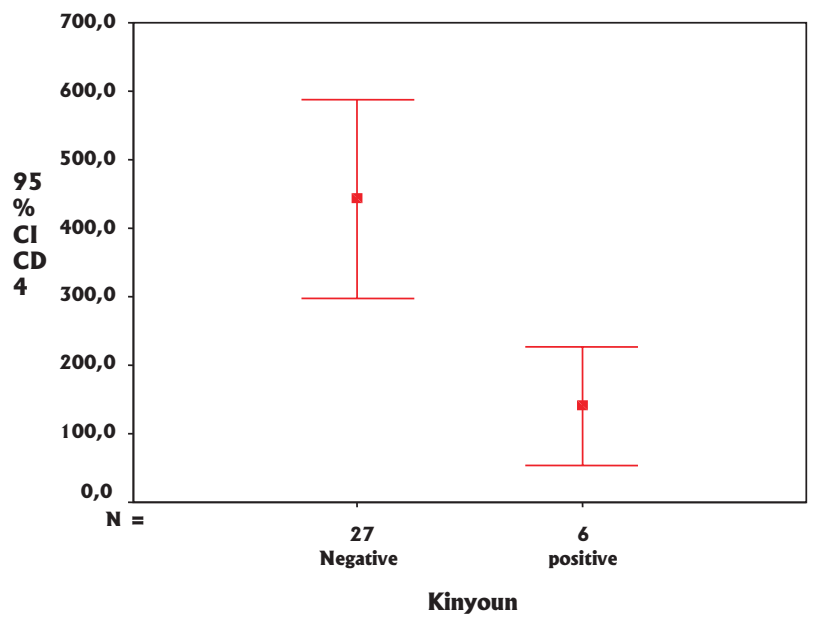

Figure 3 - Confidence Interval of 95\% for CD4 Means Analyzed Separately According to the Positive Result for Cyclospora cayetanensis. 


\section{DISCUSSION}

The occurrence of $0.3 \%$ (14/4869) in the studied population was considered low in comparison to the percentages found in Guatemala ${ }^{5}$, Peru ${ }^{13}$, Venezuela ${ }^{7}$, Haiti ${ }^{21}$, Nepal ${ }^{15}$, Egypt ${ }^{18}$, and Lagos ${ }^{1}$. A slight concentration of females ( $71 \%$ ) in the infected group in comparison to the healthy group is compatible with reports for North America².

When Student's t-test was applied ${ }^{31}$ for the comparison between the means of the levels of immunological markers, we observed that CD4, with a mean of 141 cells/ $\mu$, was statistically significant $(\mathrm{p}<0.001)$, showing that the clinical manifestations can be associated with the host's immunological markers, similarly to cryptosporidiosis ${ }^{1628}$.

When the study was analyzed regarding age range, presence of symptoms and/or associated diseases with the presence of Cyclospora cayetanensis, we observed that the clinical symptomatology in immunodepressed and immunocompetent patients, regardless of age, is not different from that caused by Cryptosporidium sp ${ }^{12021}$, with diarrhea present in $64.3 \%$ and $50 \%$ of the infected and control groups, respectively, and did not show a statistically significant association ( $p>0.05)$, emphasizing the importance of the clinical and laboratory results for the differential diagnosis of such parasites and considering the treatments described for cyclosporiasis ${ }^{2129}{ }^{20}$.

\section{REFERENCES}

1. Alakpa GE, Fagbenro - Beyioku AF. Cyclospora cayetanensis and intestinal parasitic profile in stool samples in Lagos, Nigeria. Acta Protozoologica 41:221-227, 2002

2. Amin OM. Seasonal prevalence and host relationships of Cyclospora cayetanensis in North America during 1996. Parasitology International 47: 53 - 58, 1998.

3. Araújo ALT, Teramissi LA, Mangini ACS, Freitas, EG, Hakme NA, Lins NS. Descrição de um caso de cyclosporose em paciente portador de SIDA/ AIDs, Brasília, Brasil. In: Resumos do XIII Congresso Brasileiro de Parasitologia. Revista de Patologia Tropical 23:244, 1994.

4. Ashford RW. Occurrence of an undescribed coccidian in man in Papua New Guinea. Annals of Tropical Medicine and Parasitology 73: 497-500, 1979.

5. Bern C, Arrowood MJ, Eberhard M, Maguire JM, Pratdesaba R, Torres 0, González M. Cyclospora in Guatemala: further considerations. Journal of Clinical Microbiology 40: 731-732, 2002.

6. Bonfim TCB. Parasitas gastrointestinais associados com imunodeficiência: Cryptosporidium sp, Isospora belli, Cyclospora cayetanensis e Strongyloides stercoralis. In: Resumos do XV Congresso Latino Americano de Parasitologia. Jornal Brasileiro de Patologia 37:287, 2001.

7. Chacin-Bonilla L, Young MM, Estevez J. Prevalence and pathogenic role of Cyclospora cayetanensis in a Venezuelan community. The American Journal of Tropical Medicine and Hygiene 68: 304 -306, 2003

8. Di Gliullo AB, Cribari MS, Bava AJ, Cicconetti JS, Collazos R. Cyclospora cayetanensis in sputum and stool samples. Revista do Instituto de Medicina Tropical de São Paulo 42:115-117, 2000.

9. Eberhard ML, da Silva AJ, Lilley BG, Pieniazek NJ. Morphologic and molecular characterization of new Cyclospora species from Ethiopian monkeys: C. cercopitheci sp.n., C. colobi sp.n., and C. papionis sp.n. Emerging Infectious Diseases 5: 651-658, 1999.
10. Fernandes AODP, Carollo MCC, Braz LMA, Amato Neto V, Villela MSH. Human cyclosporiasis diagnosis: report of a case in São Paulo, SP, Brazil. Revista do Instituto de Medicina Tropical de São Paulo 40: 391-394, 1998.

11. Fundação Nacional de Saúde. Secretaria de Vigilância em Saúde. SVS. In: Boletim Eletrônico Epidemiológico. Ano 02 (3) : 3-5. Disponível em: http://www. saude.gov.br, 2002.

12. Garcia L, Bruckner DA, Brewer TC, Schimizu RY. Techniques for the recovery and identification of Cryptosporidium 0ocysts from stool specimens. Journal of Clinical Microbiology 18: 185-190, 1983.

13. Garcia-Zapata MTA, Araújo JLB, Paço J, Ruano AL, Manzi RS, Souza ESJR, Faria, MLM, Cechetto FH, Fagundes GM, Barros DAC, Vieira NA, Gomes DP. Situação atual da ciclospororiase; aspectos clínico - laboratoriais, Goiânia - G0, Brasil. In: Resumos do XV Congresso Latino Americano de Parasitologia. Jornal Brasileiro de Patologia 37:277, 2001.

14. Garcia-Zapata MTA, Manzi RS, Ruano Nieto AL, Pineli LL, Faria ML, Cecchetto FH, Souza Junior ES, Otero MC, Barbosa AP. Ciclosporíase intestinal: relato dos primeiros casos humanos no estado de Goiás, Brasil. Revista de Patologia Tropical 32: 121-130, 2003.

15. Hoge CW, Echeverria P, Ramachandran R, Jacobs J, Malthouse S, Chapman E, Jimenez LM, Shlim DR. Prevalence of Cyclospora species and other enteric pathogens among children less than 5 years of age in Nepal. Journal of Clinical Microbiology 33: 3058-3060, 1995.

16. Kosek M, Alcantara C, Lima AAM, Guerrant RL. Cryptosporidiosis: an update. The Lancet Infectious Diseases 1: 262-269, 2001.

17. Lopez AS, Dodson DR, Arrowood MJ, Orlandi PA, da Silva AJ, Bier JW, Hanauer SD, Kuster RL, Oltman S, Baldwin MS, Won KY, Nace EM, Eberhard ML, Herwaldt BL. Outbreak of cyclosporiasis associated with basil in Missouri in 1999. Clinical Infectious Diseases 32: 1010-1017, 2001.

18. Nassef NE, el-Ahl As, el-Shafee OK, Nawar M. Cyclospora: a newly identified protozoan pathogen of man. Journal of the Egyptian Society of Parasitology 28: 213-219, 1998.

19. Ortega YR, Gilman RH, Sterling CR. A new coccidian parasite (Apicomplexa: Eimeridae) from humans. Journal of Parasitology 80: 625-629, 1994.

20. Ortega YR, Sterling CR, Gilman RH, Gama VA, Diaz F. Cyclospora species a new protozoan pathogen of humans. The New England Journal of Medicine 328: 1308-1311, 1993.

21. Pape JW, Verdier RI, Boncy M, Boncy J, Johnson WD. Cyclospora infection in adults infected with HIV. Annals of Internal Medicine 121: 654-657, 1994.

22. Rabold G, Hoge CN, Shlim DR, Kelford C, Rajah R, Echeverria P. Cyclospora outbreak associated with chlorinated drinking water. The Lancet Infectious Diseases 344: 1360, 1994

23. Sathyanarayanan L, Ortega Y. Effects of pesticides on sporulation of Cyclospora cayetanensis and viability of Cryptosporidium parvum. Journal of Food Protection 67: 1044-1049, 2004.

24. Schubach TM, Neves ES, Leite AC, Araújo AQC, Moura H. Cyclospora cayetanensis in an asymptomatic patient infected with HIV e HTLV-1. Transactions of the Royal Society of tropical Medicine and Hygiene 91:175, 1997

25. Secretaria de Estado de Saúde de São Paulo. INFORMENET DTA. Surtos de Doenças Transmitidas por Alimentos - Dados Estatísticos. DDTHA/CVE SES/SP. In: doenças transmitidas por alimentos - dados estatísticos - Surtos de doenças transmitidas por alimentos notificados ao CVE. Disponível em: http://www.cve.saude.sp.gov.br. São Paulo, 2000.

26. Secretaria de Estado de Saúde de São Paulo. INFORMENET DTA. Surtos de Doenças Transmitidas por Alimentos - Dados Estatísticos. DDTHA/CVE SES/SP. In: doenças transmitidas por alimentos - dados estatísticos - Surtos de doenças transmitidas por alimentos notificados ao CVE. Disponível em: http://www.cve.saude.sp.gov.br. São Paulo, 2001.

27. Shields JM, Olson BH. Cyclospora cayetanensis: a review of an emerging parasitic coccidian. International Journal for Parasitology 33: 371-391, 2003.

28. Soave R. Cyclospora: an overview. Clinical Infectious Diseases 23: 429437, 1996

29. Sterling CR, Ortega YR. Cyclospora: an enigma worth unraveling. Emerging Infectious Diseases 5: 48-53, 1999.

30. Verdier RI, Daniel W, Fitzgerald MD, Warren D, Johnson WD, Pape JW. Trimethoprim-Sulfamethoxazole compared with Ciprofloxacin for treatment and prophylaxis of Isospora belli and Cyclospora cayetanensis infection in HIV infected patients. Annals of Interne Medicine 132: 885-888, 2000.

31. Vieira S. Introdução à Bioestatística. Rio de Janeiro: Campus, 3ª edição, 1998. 